\title{
Prediction of Vapor-Liquid Equilibria and Solid-Liquid Equilibria by the Group Wilson Parameters Based on Total Vapor Pressure Data
}

\author{
Daisuke Hoshino*, Kunio Nagahama* and Mitsuho Hirata*
}

\begin{abstract}
The Analytical Solutions of Groups model by use of the group Wilson parameters is one of the useful methods to predict liquid phase activity coefficients. The group Wilson parameters for the systems consisting of $\mathrm{CH}_{2}$ groups and $\mathrm{OH}$ groups were determined using the total vapor pressure data of alcohol-water and alcohol-paraffin systems in the temperature range from $50^{\circ} \mathrm{C}$ to $90^{\circ} \mathrm{C}$. The determined group Wilson parameters were successfully used for prediction of isobaric vapor-liquid equilibria with pressures up to $20 \mathrm{~atm}$ and temperatures up to $215^{\circ} \mathrm{C}$.

Solid-liquid equilibria were also satisfactorily predicted at temperatures down to $-81^{\circ} \mathrm{C}$ using the same parameters for predicting isobaric vapor-liquid equilibria.
\end{abstract}

\section{Introduction}

The knowledge of phase equilibrium data is essential for the design of distillation, crystalization and other industrial separation equipment. However, only a limited scope of suitable experimental data is usually available when new systems are considered. It is therefore necessary to interpolate or extrapolate the existing mixture data, or when no suitable data are available, to estimate the desired equilibrium data, resorting to some appropriate method which should be able to predict the properties of a wide ranges of mixtures from the experimental data on a limited number of reference systems. The Analytical Solutions of Groups (AS OG) model is one of the useful methods to serve the purpose.

Estimation of thermodynamic properties of liquid mixtures from group contributions was first suggested by Langmuir ${ }^{22)}$. This suggestion, however, received little attention until Derr and Paradopoulos $^{11)}$, and Redlich, Derr and Pieroti ${ }^{34)}$ used group contributiuns to correlate heats of mixing, followed by Wilson and Deal ${ }^{45)}$ who developed the "Solution of Groups" model for estimating liquid phase activity coefficients. This model was expanded by Derr and Deal ${ }^{10}$ ) into the ASOG model for the prediction of liquid phase activity coefficients in terms of the parameters associated with the pairs of structual groups of a solution.

The prediction of phase equilibria by the ASOG model has been shown by Ronc and Ratcliff ${ }^{35)}$,

Received Oct. 7, 1977.

* Department of Industrial Chemistry, Faculty of Engineering, Tokyo Metropolitan University (1-1 Fukazawa, 2-chome, Setagaya-ku, Tokyo 158)
Tochigi and Kojima ${ }^{39)}$, and authors ${ }^{17)}$ for vaporliquid equilibria; by the authors ${ }^{17}$ ) for solid-liquid equilibria; and by Tochigi and Kojima ${ }^{40)}$ for liquidliquid equilibria. In this paper, the method to determine the group Wilson parameters from the total vapor pressure data is shown.

Vapor-liquid equilibria and solid-liquid equilibria were also predicted by the parameters depending on isothermal vapor-liquid equilibrium data for comparing the predicted results from the parameters depending on the total vapor pressure data. The assumption of Maripuri and Ratcliff ${ }^{23)}$ that aliphatic and aromatic carbon atoms can be treated as equivalent is used in this paper.

\section{The Analytical Solutions of Groups Model}

The Analytical Solutions of Groups (ASOG) model has been described in detail elsewhere ${ }^{10), 17), 35),}$ 39). According to the ASOG model, the activity coefficient of a component $i$ in a solution can be calculated from the following equations:

$$
\begin{aligned}
& \ln \gamma_{i}=\ln \gamma_{i}{ }^{F H}+\ln \gamma_{i}{ }^{F} \\
& \ln \gamma_{i}{ }^{F H}=\ln U_{i}+\left(1-U_{i}\right) \\
& U_{i}=\frac{\nu_{i}^{F H}}{\sum_{j=1}^{n} \nu_{j}{ }^{F H} x_{j}} \\
& \ln \nu_{i}^{G}=\sum_{k}^{N} \nu_{k i}\left(\ln \Gamma_{k}-\ln \Gamma_{k}{ }^{*}\right) \\
& \ln \Gamma_{k}=-\ln \sum_{l}^{N} X_{l} a_{k / l}+\left[1-\sum_{l}^{N} \sum_{m}^{N} X_{l} X_{m} a_{l / k}\right] \\
& X_{k}=\frac{\sum_{i=1}^{n} x_{i} \nu_{k i}}{\sum_{i=1}^{n} x_{i} \sum_{k}^{N} \nu_{k i}}
\end{aligned}
$$

where $v_{i}^{F H}$ is the number of atoms (other than hydrogen) in molecular species $i . \quad v_{k i}$ is the number 
of interacting groups of kind $k$ in molecule $i . \quad \Gamma_{k}$ is the group activity coefficient of group $k$ and $\Gamma_{k}{ }^{*}$ is the group activity coefficient of group $k$ at standard state. This standard state depends on molecule $i$. $\mathrm{a}_{k / l}, \mathrm{a}_{l / k}$ are group Wilson parameters and $X$ is the group fraction.

\section{Determination of the Group Wilson Para- meters in the Analytical Solutions of Groups Model}

For a solution containing only two groups 1 and 2, Eq. (4) is written as a function of $a_{12}$ and $a_{21}$ only at a given temperature as follows:

$$
\ln \gamma_{i}{ }^{G}=f_{i}\left(X_{1}, a_{12}, a_{21}\right)
$$

The group Wilson parameters are determined by using the total vapor pressure data and isothermal vapor-liquid equilibrium data.

Defining

$$
F=\left[\sum_{j=1}^{m} \sum_{i=1}^{n}\left(\ln \gamma_{i, \exp }^{G}-\ln \gamma_{i, \mathrm{aA1}}^{G}\right)_{j}{ }^{2}\right]
$$

where $j$ denotes the $j^{\text {th }}$ experimental point, and $F$ is a function of $a_{12}$ and $a_{21}$. Seeking the best values of $a_{12}$ and $a_{21}$ by minimizing $F$, i. e., by solving for

$$
\frac{\partial F}{\partial a_{12}}=\frac{\partial F}{\partial a_{21}}=0
$$

Eq. (9) was solved by the damped least squares fit method ${ }^{17), 35)}$.

In this paper, the group Wilson parameters were obtained from the total vapor pressure data $(P-t-x)$ but these data were taken equal to those of isothermal vapor-liquid equilibrium data $(P-t-x-y)$ in the temperature range from $50^{\circ} \mathrm{C}$ to $90^{\circ} \mathrm{C}$ of the alcohol-water and alcohol-paraffin systems which were made up with $\mathrm{CH}_{2}$ and $\mathrm{OH}$ groups. Also, using the same isothermal vapor-liquid equilibrium data $(P-t-x-y)$, the group Wilson parameters were determined for the same systems in the same range of temperature. The equilibrium data used are shown in Table 1. For simplicity, no distinction is made between $\mathrm{CH}_{3}$ and $\mathrm{CH}_{2}$ groups. The water molecule is treated as $1.6^{17), 36), 39)}$ interaction $\mathrm{OH}$

Table 1 Phase Equilibrium Data Used for the

\begin{tabular}{|c|c|}
\hline $\begin{array}{l}\text { Temp. } \\
\left({ }^{\circ} \mathrm{G}\right)\end{array}$ & System \\
\hline 50 & $\begin{array}{l}\text { Methanol-Water }{ }^{24)} \text {, Ethanol-Water }{ }^{12)} \\
\text { Ethanol-n-Heptane }\end{array}$ \\
\hline 60 & $\begin{array}{l}\text { Methanol-Water }{ }^{6)}, \text { Ethanol-Water } \\
n \text {-Propanol-Water }\end{array}$ \\
\hline 90 & $n$-Propanol-Water ${ }^{33)}, n$-Propanol-n-1)ecane ${ }^{33)}$ \\
\hline
\end{tabular}
Determination of the Group Wilson Parameters groups, and the value of $\mathrm{CH}_{2}$ group in $i$-propanol is treated as 2.817),39).

The following four methods are used to determine the group Wilson parameters:

(I) The method to determine the group Wilson parameters by using isothermal vapor-liquid equilibrium data

(I-a) Calculate $\gamma_{i}$ in Eq. (1) by the following Eq. (10).

$$
\gamma_{i}=\frac{y_{i} P}{x_{i} P_{i} s}
$$

(I-b) Calculate $\gamma_{i}$ in Eq. (1) by the following Eq. (11)

$$
\gamma_{i}=\frac{P \phi_{i}^{v} y_{i}}{x_{i} f_{i}{ }^{\circ} L}
$$

where $\phi_{i}{ }^{v}$ is the vapor phase fugacity coefficient of component $i$, and $f_{i}{ }^{\circ}{ }^{\circ}$ is the fugacity of pure component $i$ in the liquid phase. $f_{i}{ }^{\circ}$ is given by

$$
f_{i}{ }^{\circ L}=P_{i}{ }^{s} \phi_{i}{ }^{s} \exp \left[V_{i}{ }^{L}\left(P-P_{i}{ }^{s}\right) / R T\right]
$$

where $\phi_{i}{ }^{s}$ is the fugacity coefficient of pure vapor $i$ at temperature $T$ and saturation pressure $P_{i}{ }^{s}$, and $V_{i}{ }^{L}$ is the liquid molar volume of pure component $i . \quad P^{s}$ is calculated by the Antoine equation using constants of Dean ${ }^{9)}$ and Boublík, et al.5). Moreover, using the liquid molar volumes at three different temperatures ${ }^{16), 38)}$, the constants in the quadratic equations

$$
V^{L}=A+B T+C T^{2}
$$

were calculated for each component ${ }^{32}$ ). The liquid molar volumes at any temperature could then be calculated when required in the computer program by using Eq. (13). $\phi_{i}{ }^{v}$ and $\phi_{i}{ }^{s}$ are estimated from the correlation of Nagahama and Hirata ${ }^{26)}$.

(II) The method to determine the group Wilson parameters by using the total vapor pressure data

For an $n$-component mixture, the activity coefficient is represented by the Wilson equation ${ }^{44)}$ as follows:

$$
\ln \gamma_{i}=-\ln \left[\sum_{j=1}^{n} x_{j} \Lambda_{i j}\right]+\left[1-\sum_{k=1}^{n} \frac{x_{k} \Lambda_{k i}}{\sum_{j=1}^{n} x_{j} \Lambda_{k j}}\right]
$$

where,

$$
\Lambda_{i j} \equiv \frac{V_{j}^{L}}{V_{i}^{L}} \exp \left[-\frac{\left(\lambda_{i j}-\lambda_{i i}\right)}{R T}\right]
$$

The total vapor pressure of an $n$-component mixture can be calculated by Eq. (16) or Eq. (17).

$$
\begin{aligned}
& P=\sum_{i=1}^{n} \gamma_{i} P_{i}{ }^{s} x_{i} \\
& P=\sum_{i=1}^{n} \gamma_{i} f_{i}{ }^{\circ} x_{i} / \dot{\phi}_{i}{ }^{v}
\end{aligned}
$$

Usually, the total vapor pressure method is used to calculate the equilibrium vapor composition $\left(y_{i}\right)$ 
from experimental $T$ and $x_{i}$. And the method of calculation used in this paper is as follows:

Defining

$$
F=\sum_{i=1}^{n}\left(\frac{P_{e x p}-P_{c a l}}{P_{\text {exp }}} \times 100\right)_{i}^{2}
$$

where, $P_{e x p}$ is the experimental total vapor pressure and $P_{c a l}$ is calculated by Eq. (16) or Eq. (17) using experimental $T$ and $x_{i}$.

Namely, to calculate $\gamma_{i}$ of Eq. (14), a suitable parameter $\left(\lambda_{i j}-\lambda_{i i}\right)$ can be determined by pattern search method so that $F$ is minimized. From these results, the equilibrium vapor compositions are calculated from Eq. (19) or Eq. (20).

$$
\begin{aligned}
y_{i} & =\frac{\gamma_{i} P_{i}{ }^{s} x_{i}}{P_{c a l}} \\
y_{i} & =\frac{\gamma_{i} f_{j}{ }^{\circ} x_{i}}{\phi_{i}{ }^{v} P_{c a l}}
\end{aligned}
$$

(II-a) Calculate $\gamma_{i}$ in Eq. (1) by the above method using Eq. (16)

(II-b) Calculate $\gamma_{i}$ in Eq. (1) by the above method using Eq. (17)

The group Wilson parameters determined at 50, 60 and $90^{\circ} \mathrm{C}$ were listed in Table 2 and they were satisfactorily correlated with functions of absolute temperature as follows:

(I-a)

$$
\begin{aligned}
& a_{\mathrm{CH}_{2} / \mathrm{OH}}=\exp \left(-1.6952+\frac{158.3}{T}\right) \\
& a_{\mathrm{OH} / \mathrm{CH}_{2}}=\exp \left(1.4812-\frac{1803.0}{T}\right)
\end{aligned}
$$

\begin{tabular}{|c|c|c|c|}
\hline $\begin{array}{l}\text { Temp. } \\
\left({ }^{\circ} \mathrm{C}\right)\end{array}$ & $a_{\mathrm{CH}_{2} / \mathrm{OH}}$ & $a_{\mathrm{OH} / \mathrm{CH}_{2}}$ & R. M. S. D. \\
\hline $\begin{array}{r}(\mathrm{I}-\mathrm{a}) \\
50 \\
60 \\
90\end{array}$ & $\begin{array}{l}0.3005 \\
0.2935 \\
0.2840\end{array}$ & $\begin{array}{l}0.0169 \\
0.0190 \\
0.0309\end{array}$ & $\begin{array}{l}0.0890 \\
0.1121 \\
0.0491\end{array}$ \\
\hline $\begin{array}{r}(\mathrm{I}-\mathrm{b}) \\
50 \\
60 \\
90\end{array}$ & $\begin{array}{l}0.2954 \\
0.2925 \\
0.2863\end{array}$ & $\begin{array}{l}0.0179 \\
0.0185 \\
0.0348\end{array}$ & $\begin{array}{l}0.0869 \\
0.0848 \\
0.0471\end{array}$ \\
\hline $\begin{array}{c}(\mathrm{II}-\mathrm{a}) \\
50 \\
60 \\
90\end{array}$ & $\begin{array}{l}0.2955 \\
0.2830 \\
0.2886\end{array}$ & $\begin{array}{l}0.0128 \\
0.0188 \\
0.0379\end{array}$ & $\begin{array}{l}0.0617 \\
0.0738 \\
0.0318\end{array}$ \\
\hline $\begin{array}{c}(\mathrm{II}-\mathrm{b}) \\
50 \\
60 \\
90\end{array}$ & $\begin{array}{l}0.2906 \\
0.2828 \\
0.2951\end{array}$ & $\begin{array}{l}0.0144 \\
0.0198 \\
0.0368\end{array}$ & $\begin{array}{l}0.0463 \\
0.0606 \\
0.0262\end{array}$ \\
\hline
\end{tabular}

Table 2 Determined Group Wilson Parameters

R. M. S. D. $=\sqrt{\left[\sum_{j=1}^{m} \sum_{i=1}^{n}\left(\ln \gamma_{i, e x p}^{G}-\ln \gamma_{i, c a l}^{G}\right) j^{2}\right] / m}$

(I-b)

$$
\begin{aligned}
& a_{\mathrm{CH}_{2} / \mathrm{OH}}=\exp \left(-1.4973+\frac{90.3}{T}\right) \\
& a_{\mathrm{OH} / \mathrm{CH}_{2}}=\exp \left(2.3102-\frac{2066.0}{T}\right)
\end{aligned}
$$

(II-a)

$$
\begin{aligned}
& a_{\mathrm{CH}_{2} / \mathrm{OH}}=\exp \left(-1.3529+\frac{38.6}{T}\right) \\
& a_{\mathrm{OH} / \mathrm{CH}_{2}}=\exp \left(5.2781-\frac{3099.2}{T}\right)
\end{aligned}
$$

\begin{tabular}{|c|c|c|c|c|c|c|c|c|c|c|c|c|c|}
\hline \multirow{2}{*}{$\begin{array}{l}\text { System } \\
\text { Component (1) } \\
\text {-Component (2) }\end{array}$} & \multirow{2}{*}{$\begin{array}{l}\text { Press. } \\
(\mathrm{mmHg})\end{array}$} & \multirow{2}{*}{$\underset{\left({ }^{\circ} \mathrm{C}\right)}{\text { Temp. Range }}$} & \multicolumn{4}{|c|}{$\Delta y_{1} *$} & \multicolumn{4}{|c|}{$\Delta t^{*}$} & \multirow{2}{*}{$n *$} & \multirow{2}{*}{ Ref. } & \multirow{2}{*}{ Note } \\
\hline & & & $(\mathrm{I}-\mathrm{a})$ & $(\mathrm{I}-\mathrm{b})$ & (II-a) & $(\mathrm{II}-\mathrm{b})$ & $(\mathrm{I}-\mathrm{a})$ & $(\mathrm{I}-\mathrm{b})$ & $(\mathrm{II}-\mathrm{a})$ & $(\mathrm{II}-\mathrm{b})$ & & & \\
\hline $\begin{array}{l}\text { Methanol-Water } \\
\text { Ethanol-Water } \\
n \text {-Propanol-Water } \\
\text { Methanol-Ethanol } \\
\text { Methanol- } i \text {-Propanol } \\
\text { Ethanol- } i \text {-Propanol } \\
\text { Ethanol- } n-\text { Butanol } \\
i \text {-Propanol- } n \text {-Propanol } \\
\text { Methanol- } n \text {-Heptane }\end{array}$ & $\begin{array}{l}760 \\
760 \\
760 \\
760 \\
760 \\
760 \\
760 \\
760 \\
760\end{array}$ & $\begin{array}{l}64.65-100.0 \\
78.15-100.0 \\
87.7-100.0 \\
64.65-78.3 \\
64.65-82.4 \\
78.3-82.4 \\
78.3-117.5 \\
82.4-97.2 \\
58.81-98.42\end{array}$ & $\begin{array}{l}4 \\
7 \\
22.7 \\
8 \\
15 \\
2.4 \\
12 \\
5.3 \\
8\end{array}$ & $\begin{array}{l}8 \\
8 \\
24.3 \\
6 \\
12 \\
2.6 \\
7 \\
6.1 \\
5\end{array}$ & $\begin{array}{l}4 \\
7 \\
23.8 \\
8 \\
15 \\
2.4 \\
12 \\
5.3 \\
9\end{array}$ & $\begin{array}{l}9 \\
8 \\
26.7 \\
6 \\
12 \\
2.6 \\
7 \\
6.1 \\
6\end{array}$ & $\begin{array}{l}0.3 \\
0.36 \\
0.80 \\
0.3 \\
0.9 \\
0.1 \\
0.2 \\
0.2 \\
0.49\end{array}$ & $\begin{array}{l}0.6 \\
0.34 \\
0.66 \\
0.3 \\
0.8 \\
0.1 \\
0.4 \\
0.2 \\
0.21\end{array}$ & $\begin{array}{l}0.3 \\
0.35 \\
0.87 \\
0.3 \\
0.9 \\
0.1 \\
0.2 \\
0.2 \\
0.30\end{array}$ & $\begin{array}{l}0.6 \\
0.35 \\
0.76 \\
0.3 \\
0.8 \\
0.1 \\
0.5 \\
0.2 \\
0.19\end{array}$ & $\begin{array}{r}15 \\
15 \\
19 \\
12 \\
8 \\
13 \\
9 \\
14 \\
7\end{array}$ & $\begin{array}{r}8) \\
7) \\
20) \\
1) \\
3) \\
3) \\
14) \\
3) \\
4) \\
\end{array}$ & \\
\hline $\begin{array}{l}\text { Ethanol- } n \text {-Hexane } \\
\text { Ethanol- } n \text {-Heptane } \\
n \text {-Propanol- } n \text {-Hexane } \\
n \text {-Propanol- } n \text {-Heptane } \\
n \text {-Butanol- } n \text {-Octane } \\
n \text {-Butanol- } n \text {-Nonane } \\
\text { Ethanol-Benzene } \\
n \text {-Propanol-Benzene }\end{array}$ & $\begin{array}{l}760 \\
760 \\
760 \\
760 \\
760 \\
760 \\
760 \\
760\end{array}$ & $\begin{array}{r}58.4-78.32 \\
71.0-98.4 \\
65.7-97.2 \\
84.6-98.4 \\
108.5-125.7 \\
115.9-150.8 \\
67.9-80.1 \\
76.0-97.2\end{array}$ & $\begin{array}{l}15 \\
35 \\
42.5 \\
17 \\
16 \\
8 \\
31 \\
54\end{array}$ & $\begin{array}{l}17 \\
42 \\
44.9 \\
16 \\
18 \\
7 \\
29 \\
49\end{array}$ & $\begin{array}{l}15 \\
40 \\
43.4 \\
16 \\
32 \\
19 \\
31 \\
50\end{array}$ & $\begin{array}{l}16 \\
43 \\
45.3 \\
16 \\
26 \\
12 \\
30 \\
48\end{array}$ & $\begin{array}{l}1.23 \\
2.1 \\
1.5 \\
0.9 \\
0.9 \\
0.5 \\
2.5 \\
1.7\end{array}$ & $\begin{array}{l}0.88 \\
1.9 \\
1.6 \\
0.5 \\
0.9 \\
0.7 \\
2.7 \\
1.9\end{array}$ & $\begin{array}{l}1.08 \\
2.4 \\
1.6 \\
1.3 \\
2.1 \\
1.8 \\
2.5 \\
1.5\end{array}$ & $\begin{array}{l}0.75 \\
2.0 \\
1.6 \\
0.6 \\
1.5 \\
1.3 \\
2.8 \\
1.8\end{array}$ & $\begin{array}{r}9 \\
18 \\
12 \\
9 \\
10 \\
9 \\
10 \\
12\end{array}$ & $\begin{array}{l}21) \\
18) \\
29) \\
13) \\
19) \\
19) \\
27) \\
29)\end{array}$ & \\
\hline $\begin{array}{l}n \text {-Butanol- } n \text {-Heptane } \\
\text { Methanol-Water } \\
\text { Methanol-Water } \\
\text { Methanol-Water } \\
\text { Ethanol-Water } \\
\text { Ethanol-Water } \\
\text { Ethanol-Water } \\
\text { Ethanol-Water }\end{array}$ & $\begin{array}{r}1,445 \\
3,800 \\
6,080 \\
8,512 \\
2,586 \\
5,172 \\
10,344 \\
15,512\end{array}$ & $\begin{array}{l}114.8-137.0 \\
112.2-152.3 \\
129.1-169.5 \\
142.0-185.4 \\
112.6-135.6 \\
136.7-164.2 \\
164.2-194.1 \\
182.6-213.8\end{array}$ & $\begin{array}{l}26 \\
12.8 \\
14.9 \\
17.7 \\
17 \\
31 \\
43 \\
59\end{array}$ & $\begin{array}{l}31 \\
7.5 \\
5.8 \\
4.7 \\
10.1 \\
18 \\
27 \\
39\end{array}$ & $\begin{array}{l}40 \\
11.1 \\
12.6 \\
15.2 \\
13 \\
23 \\
32 \\
42\end{array}$ & $\begin{array}{l}37 \\
10.2 \\
8.6 \\
8.0 \\
5 \\
9 \\
15 \\
21\end{array}$ & $\begin{array}{l}1.2 \\
1.0 \\
0.7 \\
0.5 \\
0.6 \\
2.2 \\
3.6 \\
5.0\end{array}$ & $\begin{array}{l}1.2 \\
1.5 \\
1.3 \\
1.3 \\
0.5 \\
1.9 \\
3.5 \\
4.8\end{array}$ & $\begin{array}{l}3.0 \\
1.1 \\
1.0 \\
0.9 \\
0.4 \\
1.6 \\
2.5 \\
3.3\end{array}$ & $\begin{array}{l}2.1 \\
1.8 \\
1.6 \\
1.8 \\
0.2 \\
1.2 \\
2.2 \\
3.0\end{array}$ & $\begin{array}{l}10 \\
22 \\
22 \\
22 \\
18 \\
18 \\
18 \\
11\end{array}$ & $\begin{array}{l}43) \\
15) \\
15) \\
15) \\
28) \\
28) \\
28) \\
28)\end{array}$ & $\begin{array}{rr}5 & \text { atm } \\
8 & \text { atm } \\
11.2 \text { atm } \\
50 & \text { psia } \\
100 & \text { psia } \\
200 & \text { psia } \\
300 & \text { psia }\end{array}$ \\
\hline
\end{tabular}

(II-b)

$$
a_{\mathrm{CH}_{2} / \mathrm{OH}}=\exp \left(-1.0267-\frac{71.0}{T}\right)
$$

Table 3 Deviations of Predicted Data from Experimental Vapor-Liquid Equilibrium Data for Binary Systems

$* \Delta y_{1} *=\left[\Sigma\left|\left(y_{1, e \times p}-y_{1, c a l}\right)\right| / n\right] \times 1,000 * \Delta t^{*}=\left[\sum\left|\left(t_{e x p}-t_{c a l}\right)\right|\right] / n, * n=$ No. of data points 


$$
a_{\mathrm{OH} / \mathrm{CH}_{2}}=\exp \left(4.1176-\frac{2690.3}{T}\right)
$$

\section{Prediction of Vapor-Liquid Equilibria}

The liquid phase activity coefficients of component $i$ of vapor-liquid equilibria were calculated from Eq.(10) or Eq.(11). They can be written for the equilibrium vapor composition of component $i$ as follows:

$$
\begin{aligned}
& \sum_{i=1}^{n} y_{i}=\sum_{i=1}^{n} \gamma_{i} P_{i}{ }^{s} x_{i} / P=1 \\
& \sum_{i=1}^{n} y_{i}=\sum_{i=1}^{n} \gamma_{i} f_{i}{ }^{\circ} x_{i} / \phi_{i}{ }^{v} P=1
\end{aligned}
$$

The activity coefficients in Eq.(29) are predicted by using Eqs. (1) to (6) with parameters (I-a) and (IIa), and the activity coefficients in Eq.(30) are predicted by using also Eqs.(1) to (6) but with parameters (I-b) and (II-b).

The predicted results for the 25 isobaric vaporliquid equilibria of alcohol-water, alcohol-alcohol, alcohol-paraffin and alcohol-aromatic hydrocarbon systems are shown in Table 3 with the absolute arithmetic mean deviations between experimental and predicted vapor compositions and temperature data. The benzene molecule is treated as 6.0 interaction $\mathrm{CH}_{2}$ group.

Figs. 1 and $\mathbf{2}$ show the predicted vapor-liquid equilibria with respect to parameter (II-b) to the deviation of experimental temperature with the composition data for ethanol- $n$-butanol and ethanolwater systems, respectively.

The predicted results in Table 3 and Figs. 1 and 2 show good agreement with those of the experi-

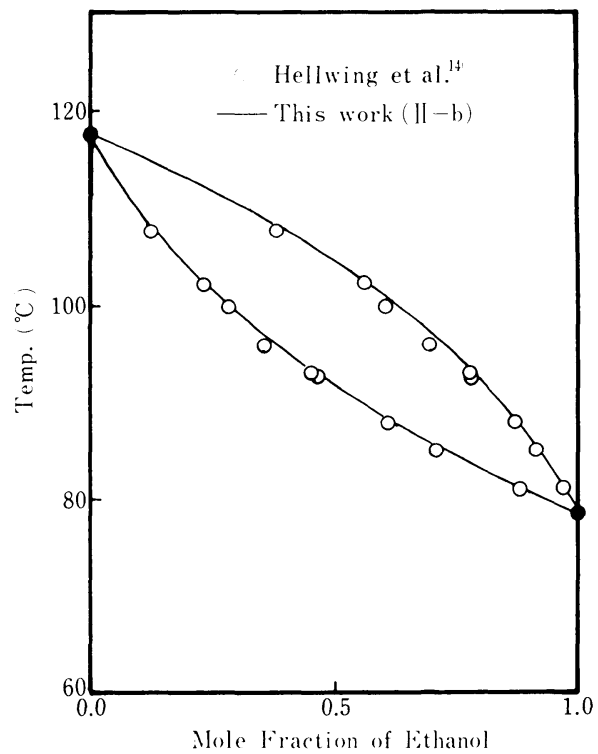

Fig. 1 Temperature-Composition Diagram for Ethanol (1)-n-Butanol (2) System at $760 \mathrm{mmHg}$

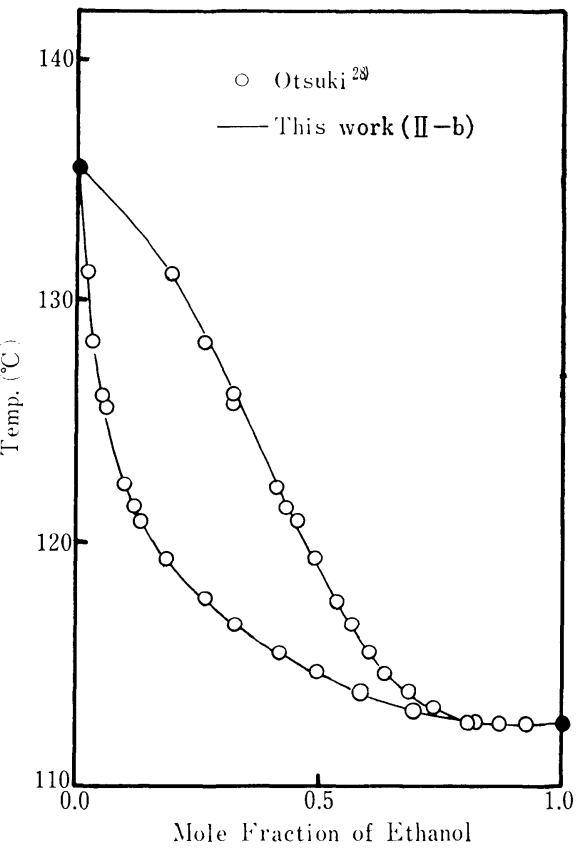

Fig. 2 Temperature-Composition Diagram for Ethanol (1)-Water (2) System at 2, $586 \mathrm{mmHg}$

ments.

\section{Prediction of Solid-Liquid Equilibria}

The liquid phase activity coefficients for the solute component $i$ of solid-liquid equilibria in which the solid phase is assumed to be the pure solute and the liquid phase is a saturated solution of the solute in the solvent can be determined by the simple Van't Hoff isochore equation, i.e.

$$
\ln \gamma_{i} x_{i}=\frac{\Delta H_{i}}{R T} \frac{\left(T-T_{i}{ }^{M}\right)}{T_{i}{ }^{M}}
$$

where $\Delta H_{i}$ is the heat of fusion of the solute component $i$ and $T_{i}{ }^{M}$ is the temperature of melting point of the solute component $i$.

The activity coefficients in Eq.(31) are predicted by using Eqs.(1) to (6).

The predicted results for solid-liquid equilibria of naphthalene-alcohol and benzene-alcohol systems are listed in Table 4 with the absolute arithmetic mean deviations between experimental and predicted liquid compositions. Figs. 3 and $\mathbf{4}$ show the predicted solid-liquid equilibria with respect to parameter (II-b) to the deviation of experimental temperature with the liquid composition data for naphthalene- $i$-butanol and benzene- $i$-propanol systems. Assuming the systems ideal, i.e. $\gamma_{i}$ in Eq.(31) is taken to be 1.0, the calculated results are also plotted in Figs. 3 and 4.

The predicted solid-liquid equilibrium data shown in Table 4 and Figs. 3 and $\mathbf{4}$ indicated good agree- 
Table 4 Deviations of Predicted Data from Experimental Solid-Liquid Equilibrium Data for Binary Systems

\begin{tabular}{|c|c|c|c|c|c|c|c|}
\hline \multirow{2}{*}{$\begin{array}{c}\text { System } \\
\text { Component (1)-Component (2) }\end{array}$} & \multicolumn{4}{|c|}{$\Delta x_{1} *$} & \multirow{2}{*}{ Temp. Range $\left({ }^{\circ} \mathrm{C}\right)$} & \multirow{2}{*}{$n *$} & \multirow{2}{*}{ Ref. } \\
\hline & $(\mathrm{I}-\mathrm{a})$ & $(\mathrm{I}-\mathrm{b})$ & $(\mathrm{II}-\mathrm{a})$ & $(\mathrm{II}-\mathrm{b})$ & & & \\
\hline Naphthalene-Ethanol & 55.1 & 49.9 & 57.2 & 53.2 & $20.0-80.0$ & 11 & 2) \\
\hline Naphthalene- $n$-Propanol & 38.6 & 34.8 & 42.4 & 38.5 & $20.0-80.0$ & 11 & 2) \\
\hline Naphthalene- $i$-Propanol & 45.9 & 41.0 & 48.6 & 44.9 & $20.0-80.0$ & 11 & 2) \\
\hline Naphthalene- $n$-Butanol & 32.2 & 28.8 & 37.6 & 33.1 & $25.0-80.0$ & 10 & 2) \\
\hline Naphthalene- $i$-Butanol & 30.4 & 26.9 & 31.6 & 28.2 & $20.0-80.0$ & 11 & 2) \\
\hline Benzene- $n$-Propanol & 27.3 & 32.8 & 69.6 & 54.6 & $-78.6-5.5$ & 8 & $31)$ \\
\hline Benzene- $i$-Propanol & 30.6 & 37.0 & 58.0 & 52.4 & $-79.0-5.5$ & 12 & 30) \\
\hline Benzene- $n$-Butanol & 39.4 & 40.9 & 49.2 & 45.9 & $-81.0-5.5$ & 12 & $30)$ \\
\hline
\end{tabular}

$* \Delta x_{1} *=\left[\sum\left|\left(x_{1, e x p}-x_{1, c a l}\right)\right| / N\right] \times 1,000 * n=$ No. of data points

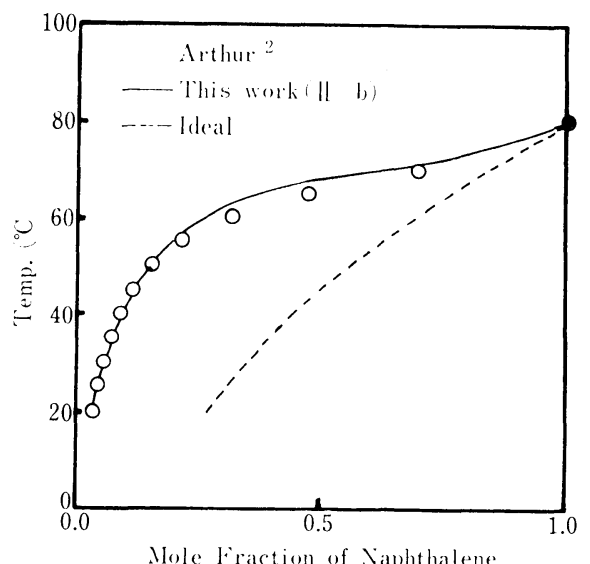

Fig. 3 Solubility Diagram of Solid Naphthalene in Liquid Phase for Naphthalene (1)-i-Butanol (2) System

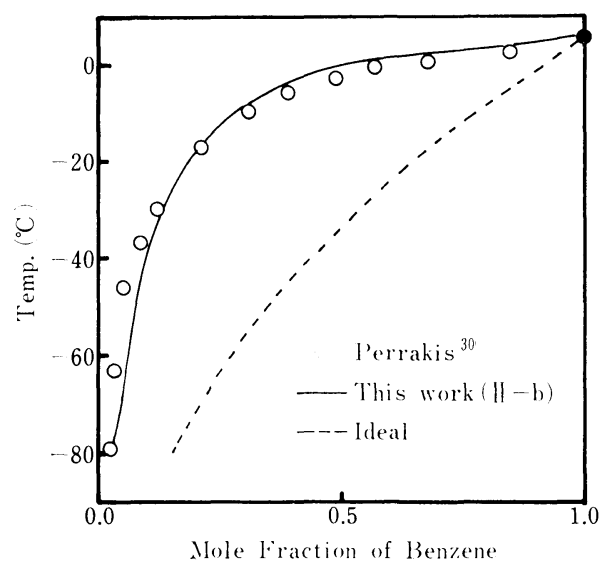

Fig. 4 Solubility Diagram of Solid Benzene in Liquid Phase for Benzene (1)-i-Propanol (2) System

ment with those of the experiments.

The naphthalene molecule is treated as 10.0 interaction $\mathrm{CH}_{2}$ groups and the value of $\mathrm{CH}_{2}$ group in $i$-butanol is taken as 3.8, which was of the same treatment as Tochigi and Kojima ${ }^{39)}$ and the authors ${ }^{17}$. $\triangle H$ for naphthalene is taken from Timmermans ${ }^{38)}$ and $\Delta H$ for benzene is taken from Dean ${ }^{9}$.

\section{Conclusions}

The group Wilson parameters for the systems consisting of $\mathrm{CH}_{2}$ and $\mathrm{OH}$ groups were determined using the total vapor pressure data of alcohol-water and alcohol-paraffin systems at temperatures 50,60 and $90^{\circ} \mathrm{C}$. The isobaric vapor-liquid equilibria of the binary systems involving alcohols, water, paraffins and benzene were satisfactorily predicted even within the temperature range from $90^{\circ} \mathrm{C}$ to $215^{\circ} \mathrm{C}$ and pressures up to $20 \mathrm{~atm}$. Also, solid-liquid equilibria of the naphthalene-alcohol and benzenealcohol systems were successfully predicted at temperatures down to $-81^{\circ} \mathrm{C}$ utilizing the same parameters for predicting isobaric vapor-liquid equilibria.

(The 11 th Autumn Meeting of The Soc. of Chem. Engrs., Japan at Tokyo, Oct. 5, 1977)

\section{Nomenclature}

$$
\begin{aligned}
& A, B, G=\text { Antoine constant } \quad[-] \\
& a=\text { group Wilson parameter } \quad[-] \\
& f_{i}^{\circ L}=\text { fugacity of pure component } i \text { in the } \\
& \text { liquid phase } \\
& \text { [mmHg] } \\
& \Delta H=\text { heat of fusion } \quad[\mathrm{cal} / \mathrm{g}-\mathrm{mol}] \\
& m=\text { number of data points used to deter- } \\
& \text { mine the parameters }[-] \\
& N=\text { number of groups } \quad[-] \\
& n=\text { number of components } \quad[-] \\
& P=\text { total vapor pressure } \quad[\mathrm{mmHg}] \\
& P^{s}=\text { vapor pressure of pure liquid compo- } \\
& \text { nent } \\
& {[\mathrm{mmHg}]} \\
& R=\text { gas constant } \quad[\mathrm{cal} / \mathrm{g}-\mathrm{mol} \cdot \mathrm{K}] \\
& T=\text { absolute temperature } \quad[\mathrm{K}] \\
& U=\text { solute group ratio } \quad[-] \\
& V^{L}=\text { liquid molar volume } \quad[\mathrm{cc} / \mathrm{g}-\mathrm{mol}] \\
& X=\text { group fraction } \quad[-] \\
& x=\text { mole fraction in liquid phase } \quad[-] \\
& y=\text { mole fraction in vapor phase } \quad[-] \\
& \Gamma=\text { group activity coefficient } \quad[-] \\
& \gamma=\text { activity coefficient } \quad[-] \\
& \lambda_{i j}-\lambda_{i i}=\text { Wilson parameter } \quad[\mathrm{cal} / \mathrm{g}-\mathrm{mol}] \\
& \nu_{i}{ }^{\prime I I}=\text { number of atoms (other than } \\
& \text { hydrogen) in molecular species } i \quad[-]
\end{aligned}
$$


$\nu_{k i}=$ number of interacting groups of kind $k$ in molecule $i$ $\phi^{v}=$ vapor phase fugacity coefficient $\quad[-]$ $\phi^{s}=$ pure vapor fugacity coefficient $\quad[-]$

\section{Subscripts}

$1,2, i, j=$ molecule $1,2, i$ and $j$

$k, l, m=\operatorname{group} k, l$ and $m$

$k i=\operatorname{group} k$ in molecule $i$

$c a l=$ calculated

\section{Superscripts}

$$
\begin{aligned}
F H & =\text { size contribution } \\
G & =\text { group contribution } \\
L & =\text { liquid phase } \\
M & =\text { melting point } \\
S & =\text { pure component } \\
V & =\text { vapor phase }
\end{aligned}
$$

\section{References}

1) Amer, H. H., Paxton, R. R., van Winkle, M., Ind. Eng. Chem., 48, 142 (1956).

2) Arthur, A. S., J. Phys. Chem., 34, 2582 (1930).

3) Ballard, L. H., van Winkle, M., Ind. Eng. Chem., 44, 2450 (1952).

4) Benedict, M., Johnson, A., Solomon, E., Rubin, L. C., Trans. Am. Inst. Chem. Eng., 41, 371 (1945).

5) Boublík, T., Fried, V., Hála, E., "The Vapor Pressures of Pure Substances”, (1973), Elsevier Scientific Publishing Company, Amsterdam.

6) Broul, M., Hlavaty, K., Linek, J., Collection Czech. Chem. Commun., 34, 3428 (1969).

7) Carey, J. S., Lewis, W. K., Ind. Eng. Chem., 24, 882 (1932).

8) Chu, J. C., Getty, R. J., Brennecke, L. F., Paul, R., "Distillation Equilibrium Data", (1950), Reinhold.

9) Dean, J. A., Ed., "Lange's Handbook of Chemistry", 11 ed., (1970), McGraw-Hill, Inc., New York.

10) Derr, E. L., Deal, C. H., I. Chem. E. Symposium Series, 32, p. 3: 40 (1969).

11) Derr, E. L., Papadopoulos, M., J. Am. Chem. Soc., 81, 2285 (1959).

12) Dulitskaya, K. A., Zh. Obshch. Khim., 15, 9 (1945).

13) Gurukul, S. M. K. A., Raju, B. N., J. Chem. Eng. Data, 11, 501 (1966).

14) Hellwing, L. R., van Winkle, M., Ind. Eng. Chem., 45, 624 (1953).

15) Hirata M., Suda, S., Kagaku Kogaku, 31, 759 (1967).

16) Holmes, M. J., van Winkle, M., Ind. Eng. Chem., 62, $21(1970)$.

17) Hoshino, D., Unno, Y., Nagahama, K., Hirata, M.
Bull. Japan Petrol. Inst., 19, (1), 56 (1977).

18) Katz, K., Newman, M., Ind. Eng. Chem., 48, 137 (1956).

19) Kogan, V. B., Fridman, V. M., Romanovai. T. G., Zh. Fiz. Khim., 29, 685 (1955).

20) Kojima, K., Kato, M., Sunaga, H., Hashimoto, S., Kagaku Kogaku, 32, 337 (1968).

21) Kudryavtseva, L. S., Susarev, M. P., Zh. Prikl. Khim., 36, 1231 (1963).

22) Langmuir, I., "The Distribution and Orientation of Molecules", Third Colloid Symposium Monograph, (1925), The Chemical Catalog Company, Inc.. New York.

23) Maripuri, V. C., Ratcliff, G. A., Canadian J. Chem. Eng., 49, 506 (1971).

24) Mcglashan, M. L., Williamson, A. G., J. Chem. Eng. Data, 21, 196 (1976).

25) Murti, P. S., van Winkle, M., Chem. Eng. Data Series, 3, 72 (1958).

26) Nagahama, K., Hirata, M., J. Chem. Eng. Japan, 3, $146(1970)$

27) Niini, A., Ann. Acrd. Sci. Fenn., A 55, No. 8 (1940).

28) Otsuki, H., Williams, F. C., Chem. Eng. Prog. Symp. Series, 49, (6), 55 (1953).

29) Parabhu, P. S., van Winkle, M., J. Chem. Eng. Data, 8, 210 (1963).

30) Perrakis, N., J. Chim. Physique, 22, 280 (1925).

31) Pickering, S. U., J. Chem. Soc. (London), 63, 998 (1893).

32) Prausnitz, J. M., Eckert, G. A., Orye, R. V., O'Connell, J. P., "Computer Calculations for Multicomponent Vapor-Liquid Equilibria", (1967), Prentice Hall, Englewood Cliffs, New Jersey.

33) Ratcliff, G. A., Chao, K. G., Canadian J. Chem. Eng., 47, 148 (1969).

34) Redlich, O., Derr, E. L., Pierotti, G., J. Am. Chem. Soc., 81, 2283 (1959).

35) Ronc, M., Ratcliff, G. A., Canadian J. Chem. Eng., 49, 825 (1971)

36) Scheller, W., Ind. Eng. Chem. Fundamentals, 4, 459 (1965).

37) Smith, C. P., Engel, E. W., J. Am. Chem. Soc., 51, 2660 (1929).

38) Timmermans, J., "Physico-Chemical Constants of Pure Organic Compounds" Vol.1, (1965), Elsevier.Publishing Company, Amsterdam.

39) Tochigi, K., Kojima, K., J. Chem. Eng. Japan, 9, 267 (1976).

40) Tochigi, K., Kojima, K., ibid, 10, 61 (1977).

41) Udovenko, V.V., Fatkulina, L.G., Zh. Fiz. Khim.. 26, 1438 (1952).

42) van Ness, H.G., Soczek, G.A., Peloquin, G.L., Machado, R.L., J. Chem. Eng. Data, 12, 217 (1967).

43) Vijayaraghavan, S.V., Deshpande, P.K., Kuloor, N.R., ibid., 12, 15 (1967).

44) Wilson, G.M., J. Am. Chem. Soc., 86, 127 (1964).

45) Wilson, G.M., Deal, C.H., Ind. Eng. Chem. Fundamentals, 1, 20 (1962). 
要旨

\title{
全圧データに基づくグループ Wilson パラメータを用いた気液平衡および固液平衡の推算
}

\author{
星野 大輔*, 長浜 邦雄*, 平田 光穂*
}

グループ Wilson パラメータを用いる解析的グループ溶液モ デル（ASOG モデル）は，液相活量係数を推算する有用な方 法の一つである10)。すでに，ASOG モデルによる相平衡の推

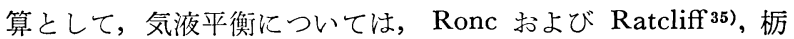
木および小島 ${ }^{39)}$ ，筆者ら ${ }^{17)}$ の研究が，固液平衡については筆者 ら 17)の研究が，さらに液液平衡については杤木および小島40)の 研究がある。

グループ溶液モデルにおける混合物中の成分 $i$ の活量倸数 $\gamma_{i}$ は, Eqs. (1)〜(6) で表わされる。Eq. (5) 中の $a_{l / k}, a_{l^{\prime} k} k$ が グループ Wilson パラメータである。

本研究では， $\mathrm{CH}_{2}$ と $\mathrm{OH}$ から成る系の検討を目的とし，(8) 式で示した目的関数 $F$ が最小となるような, グループ Wilson パラメータを修正 Newton 法 ${ }^{17), 35)}$ によって求めた。Table 1 に，パラメータ決定に用いた $50^{\circ} \mathrm{C}$ から $90^{\circ} \mathrm{G}$ の $\mathrm{CH}_{2}$ と $\mathrm{OH}$ から成るアルコールー水, アルコールーパラフィン系の定温気液 平衡データ $(P-T-x-y)$ を示した。をた, Table 1 に示した定 温気液平衡データ $(P-T-x-y)$ の $y$ を除いた $(P-T-x)$ を全圧 データとして用いた。

パラメータの決定に次の四つの方法を用いた。

（I）定温気液平衡データを用いる方法

(I-a) Eq.(1)中の $\gamma_{i}$ をE.(10)で求めて,グループ Wilson

* 東京都立大学工学部工業化学科 (158 東京都世田谷区深 沢 2-1-1)

\section{Keyword}

Equilibria, Group Wilson parameter, Prediction, Solid-liquid, Vapor-liquid
パラメータを求める方法

(I-b) Eq.(1) 中の $\gamma_{i}$ を Eq.(11) で求めて,グループ Wilson パラメータを求める方法

（III） 全圧データを用いる方法

（II-a） Eq. (16) を用いて全圧を計算し，その時計算される $\gamma_{i}$ を Eq. (1) に用いて, グループ Wilson パラメータを求 める方法

（II-b） Eq. (17) を用いて全圧を計算し，その時計算される $\gamma_{i}$ を Eq. (1) に用いて，グループ Wilson パラメータを求 める方法

以上の四つの方法によって決定した,グループ Wilson パラメ 一タを Table 2 に示した。また，それらのパラメータを，Eqs． (21)〜(28) で相関した。決定したグループ Wilson パラメータ 〔Eqs. (21) 〜 (28)]を用いて, 温度 $58 \sim 214^{\circ} \mathrm{C}$, 圧力 $1 \sim 20 \mathrm{~atm}$ までの定圧気液平衡の推算を行い，実測值と比較しその結果を

Table 3 と Figs. 1, 2 に示したところ, 推算值は実測值と良 好な一致を示した。同様にして, $80 \sim-81^{\circ} \mathrm{C}$ の温度範囲の固 液平衡の推算を行い，実測値と比較しその結果を Table 4 と Figs. 3，4 に示したところ，推算值は実測值と良好な一致を 示した。

本研究では, $\mathrm{CH}_{3}$ グループは $\mathrm{CH}_{2}$ グループとして扱い, ベ ンゼンおよびナフタレンはそれぞれ $\dot{\mathrm{C}}_{2} 6$ グループおよび $\mathrm{CH}_{2} 10$ グループより成るものとした ${ }^{23)}$ 。た， $i$-プロパノー ルおよび $i$-ブタノールの $\mathrm{CH}_{2}$ グループ数は，それぞれ 2.8

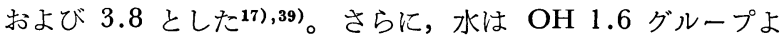
り成るものとして扱った ${ }^{17), 36), 39) 。 ~}$ 